\title{
A New Genotype for White Seed Coat Discovered in 'Early Wax' Snap Bean
}

\author{
Mark J. Bassett and Arie Blom ${ }^{2}$ \\ Vegetable Crops Department, IFAS, University of Florida, Gainesville, FL 32611
}

Additional index words. Phaseolus vulgaris, common bean

\begin{abstract}
The white-seeded snap bean 'Early Wax' (Phaseolus vulgaris L.) was crossed with a black-seeded breeding line 5-593. The $\mathrm{F}_{2}$ segregation data are consistent with a three-gene model, in which all three genes must be homozygous recessive to give white seed coat. One of the genes is $t$ because of segregation in $F_{2}$ for plants with white flowers and partial seed coat coloration. We hypothesize that the genes ers and ers 2 in the presence of $f$ block all seed color expression in all genes for partial coloration of seed. The hypothesis of three recessive genes was confirmed in a backcross test involving 'Early Wax' $\mathbf{x} \mathbf{F}_{1}$. The interaction of ers and ers 2 was tested in progeny tests of partly colored BC-F ${ }_{1}$ plants. One of the erasure genes, ers2, blocks color expression in color zones close to the hilum, but only in the presence of ers. The other erasure gene, ers, blocks color expression only in color zones beyond those close to the hilum in a manner similar to the restr locus of Prakken (1972). The old hypothesis that partly colored seed phenotypes require the presence of a second factor $e$ in addition to $t$, where the function of $e$ is vague and unspecified, should be discarded for lack of supporting evidence, Under the new hypothesis, soldier series phenotypes (e.g., bipunctata, arcus, virgata, and virgarcus) may express in $t$ ers Ers 2 by action of ers or in $t$ Ers Ers 2 by action of various genes for partly colored seeds other than ers.
\end{abstract}

Among commercial cultivars of common bean, white seed coat is nearly always produced by the recessive genotype $p$. It is desirable to find as many alternative genotypes as possible for white seed coat because $p$ causes poor line performance (Dickson and Petzoldt, 1988). It is possible that other genotypes for white seed coat may be less deleterious than $p$. This hypothesis presupposes that the blocks in pigment biosynthesis at these other genes for white seed coat will not have the same secondary effects as the block at $p$. The literature on seed coat color genetics and pigment chemistry was recently reviewed by Leakey (1988).

White seed coat in common bean can be produced by at least five genotypes that were reported by Lamprecht (1961): 1) When the ground factor gene, $p$, is present in its homozygous recessive form, the seed coat is pure white. 2) When the second ground factor gene, gri, is present in a homozygous recessive form, genotypes with $P$ and recessive for all basic color genes and color modifying genes, except $\mathrm{C}$ and $R$, result in pure white seeds. The testa colors caused by dominant alleles at color genes other than $C$ and $R$ are reduced to gray white in the presence of gri. 3) When no color genes $[C, J$, and $D$ in the symbols of Prakken (1970)] are present in dominant form, seeds with $P$ also have pure white seed coats. 4) The glaucescens testa color produced by the genotype $P V$ is reduced to pure white by the modifier gene inh. 5) When the recessive basic genes for partial coloration, $\mathrm{t}$ and $\mathrm{e}$, are present and recessive alleles are present at all the partial coloration loci, $z$, arc, bip, diff, and exp, the seed coat is pure white.

In this paper we will present evidence that the fifth white genotype explanation is not correct. Furthermore, Lamprecht did not cite the work of Schreiber $(1934,1940)$ that demonstrated that a dominant $L$ gene, in the presence of $t$ and various partial coloration genes, produces pure white seed coats. The $L$

Received for publication 27 Dec. 1989. Fla. Agr. Expt. Sta. Journal Series no. $\mathrm{R}-00342$. The cost of publishing this paper was defrayed in part by the payment of page charges. Under postal regulations, this paper therefore must be hereby marked advertisement solely to indicate this fact.

'Professor.

${ }^{2}$ Former student. Present address: Rijnsteeg 8-12C, 6708 PP Wageningen, The Netherlands. gene extinguishes the effects of partial coloration genotypes. We also will present evidence for the existence of genes other than $L$ that extinguish the effects of partial coloration genes in the presence oft, thus producing pure white seed coats.

\section{Materials and Methods}

'Early Wax' is a snap bean with bush habit, yellow wax pods, white flowers, and white seeds. Previous work has shown that the white seed coat in 'Early Wax' is not due top, but to some unknown genotype (Dickson and Petzoldt, 1988). It was the suggestion by M.H. Dickson (personal communication) to investigate 'Early Wax' for a new white seed genotype that inspired this research. Breeding line 5-593 is a dry bean with bush habit, green pods, purple flowers, and black seeds. The cross 'Early Wax' x 5-593 was made, and the $F_{1}$ generation was grown in the greenhouse. The $\mathrm{F}_{2}$ was grown in the field in 1987 and classified for flower color by tagging each plant that had white flowers. A seed sample was harvested from each $\mathrm{F}_{2}$ plant, and the seed was classified for color and for the presence of partial coloration of the seed. Selection was made for $\mathrm{F}_{2}$ plants with white flowers and white seeds.

Seed for four additional plant populations was produced in the winter greenhouse season of 1987-88. From remnant $F_{1}$ seed of the cross 'Early Wax' $\times 5-593$, new $\mathrm{F}_{2}$ seed was produced. Using the same $F_{1}$ plants, backcrosses to 'Early Wax' were made. Also, an $\mathrm{F}_{2}$ selection (7-480 WFS) for white flowers and white seeds was crossed to 'Early Wax' to perform an allelism test. The cross 7-480 WFS x 5-593 was made and $F_{2}$ seed produced. These four seed populations were planted in the field in 1988. All plants were classified for flower color, seed color, and partial coloration of the seeds. Selection was made for $F_{2}$ plants with white flowers and white seeds.

Several experimental plant populations were produced in the winter greenhouse season of 1988-89. A second backcross to 5-593 was made with selection 8-525 WFS, which is a selection for white flowers and white seeds from $\mathrm{BC}_{1}-\mathrm{F}_{2}$. New seed was produced of the backcross 'Early Wax' x $\mathrm{F}_{1}$ ('Early Wax' x 5593), and the $F_{1}$ was grown in the greenhouse and classified for flower color, seed color, and partial coloration of the seeds. Twenty-three plants with partly colored seeds were selected for 
progeny tests. Seed of the $\mathrm{BC}_{2}-\mathrm{F}_{2}$ and $23 \mathrm{BC}_{1}-\mathrm{F}_{2}$ progenies were planted in the field. All plants were classified for flower color, seed color, and partial coloration of the seeds.

The field plots were planted in raised beds spaced $1.22 \mathrm{~m}$ apart. Two rows spaced $0.3 \mathrm{~m}$ apart were planted on each bed, and the plants were spaced $20 \mathrm{~cm}$ apart (in row) for experimental convenience. Standard cultural practices were used for irrigation, fertilization, and weed control.

\section{Results and Discussion}

'Early Wax' $\times 5-593 F_{2}$. The $\mathrm{F}_{2}$ progeny of the cross 'Early Wax' $\times 5-593$ gave a good fit to a 9:7 ratio for purple : white flower color in both years, and the combined data also fit the 9:7 (purple : white) ratio (Table 1). We hypothesize that two recessive genes, each producing white flower color independently of the other, are segregating in the $\mathrm{F}_{2}$. One of these recessive genes is $t$ because the $\mathrm{F}_{2}$ segregates for partial seed coloration (Table 1). Previous reports (Lamprecht, 1935; Prakken, 1934) have shown that $t$ has two effects on the phenotype: white flowers rather than purple and partial coloration of seeds rather than solid color.

Emerson (1909) proposed a second gene, E, that is required for expression of colored seeds ("self-colored" in Emerson's usage), but he did not publish genetic data to confirm the existence of this gene. In a small $\mathrm{F}_{2}$ population, Sax (1923) obtained a better fit to a 45:3:16 (colored : partly colored : white) ratio than to a 9:3:4 ratio, and he hypothesized that the double recessive $t e$ was necessary for partly colored (eye) expression. Sax did not test his hypothesis with any other experiments, and no other investigator has ever reported a 15:1 ratio between colored and partly colored segregants. In the work of Lamprecht (1940a) the action of e was uncertain, other than the statement that $t e$ is required for expression of partly colored seeds and that these genes may have some unspecified effect on the pattern of partial coloration. We believe that this vague second factor hypothesis and its symbol e should be discarded for lack of supporting evidence.

The second gene for white flower color in the $\mathrm{F}_{2}$ of 'Early Wax' $\mathrm{x} 5-593$ is $v$. The key evidence for this conclusion is the segregation of brown seed color within the white-flowered class, but not in the purple-flowered class. It is well-established (Lamprecht, 1948) that an allele substitution at $V$ changes flower color from purple $(V)$ to white $(v)$. The $V$ locus has a pleiotropic effect on seed coat color (Prakken. 1970), changing black (CdJGBV) to mineral brown (CdJGBv).

Table 1. 'Classification of $\mathrm{F}_{2}$ common bean progeny from the cross 'Early Wax' x 5-593 for flower color, seed color, and partial coloration of the seed.

\begin{tabular}{|c|c|c|c|c|c|c|}
\hline \multirow[b]{4}{*}{ Year } & \multicolumn{6}{|c|}{ Flower color ${ }^{z}$} \\
\hline & \multirow{3}{*}{$\begin{array}{c}\text { Purple } \\
\text { Solid } \\
\text { black } \\
\text { seed }\end{array}$} & \multicolumn{5}{|c|}{ White } \\
\hline & & \multicolumn{3}{|c|}{ Solid seed color } & \multicolumn{2}{|c|}{ Partial seed color } \\
\hline & & Brown & Black & White $^{y}$ & Black & Brown \\
\hline & \multicolumn{6}{|c|}{ No. of plants } \\
\hline 1987 & 233 & 66 & 13 & 5 & 56 & 19 \\
\hline 1988 & 373 & 134 & 7 & 12 & 108 & 24 \\
\hline
\end{tabular}

${ }^{2}$ The $x^{2}(9: 7)$ for purple : white flower color segregation was $1.62(\mathrm{P}$ $=0.20)$ for 1987 and $0.05(\mathrm{P}=0.82)$ for 1988 . The $x^{2}(9: 7)$ for the combined data for both years was $0.91, P=0.34$.

'The $x^{2}(63: 1)$ for colored (including partly colored) seed : white seed was $0.21(P=0.65)$ for 1987 and $0.29(P=0.59)$ for 1988 . The $x^{2}$ (63:1) for the combined data for both years was $0.41, P=0.52$.
Yarnell (1965) reviewed the literature on the genetics of partly colored seeds, and a tabular summary of the more pertinent findings is provided in Table 2. The classes bipunctata through piebald are best illustrated by Lamprecht (1934, 1940a). The concept of "color centers" was developed and illustrated by Prakken (1972). Leakey (1988) has also reviewed and illustrated what is known about the genetics of partly colored seeds.

According to Lamprecht (1940a), every partial coloration genotype in his genetic model produces an area of color on the seedcoat. The genotype bip arc gives bipunctata, the minimum colored area reported in that paper. Elsewhere, Lamprecht (1934) reported a unipunctata phenotype, but did not give any genotypic model. All genotypes other than bip arc that were published by Lamprecht (1940a) give greater areas of color than bipunctata. We cannot account for white seed coats based on the partial, coloration genes of Lamprecht or other researchers (Emerson, 1909; Lamprecht, 1934, 1940a; Miyake et al., 1930; Schreiber, 1934, 1940; Tschermak, 1912), except for the $L$ gene as explained below.

Table 2. Genotypes corresponding to particular patterns on partly colored common bean seeds as summarized by Yarnell (1965) and us.

\begin{tabular}{lcl}
\hline \hline & $\begin{array}{c}\text { Partly colored } \\
\text { seed coat } \\
\text { pattern }\end{array}$ & $\begin{array}{l}\text { Description of } \\
\text { seed coat pattern }\end{array}$ \\
\hline
\end{tabular}

$\begin{array}{ll}\text { te } z \text { arc bip Mic } & \\ M i & \text { Bipunctata Two dots at caruncular and micro- }\end{array}$

te $z$ arc Bip mic pilar ends of hilum

$M i \quad$ Arcus Two arcs originating at caruncula and proceeding along both sides of hilum

\begin{tabular}{|c|c|}
\hline${ }_{m i}^{t e z A r c ~ b i p ~ M i c ~}$ & Virgata \\
\hline $\begin{array}{l}\text { te } z \text { Arc Bip Mic } \\
\text { mi }\end{array}$ & Virgarcus \\
\hline te $z$ & Eye \\
\hline$t e Z$ & Sellatus \\
\hline$t e Z / z$ & Piebald \\
\hline $\begin{array}{l}t \text { E Arc Bip Diff } \\
\text { Exp }\end{array}$ & Maximus \\
\hline
\end{tabular}

Caruncula spot, micropile spot, and micropile stripe

Same as arcus, but has micropile stripe (from micropile to end of seed)

Complete (or nearly complete) but narrow circle of colored zones around hilum

Broad circle of colored area around hilum

Top half (centered on hilum) of seed is colored

About $1 / 4$ of seed is colored with zone broader at caruncula end of seed than micropile end

$\begin{array}{ll}t \text { E Arc bip diff } & \\ \text { Exp } & \text { Major } \\ & \\ \begin{array}{ll}\text { E Arc Bip Diff } \\ \exp \end{array} & \\ & \text { Minor } \\ \begin{array}{ll}\text { E Arc bip diff } \\ \exp \end{array} & \\ & \end{array}$

About $1 / 2$ of seed is colored, with color covering entire caruncula end of seed

About $3 / 4$ of seed colored, with micropilar end white (skewed toward dorsal side of seed)

Only a small patch of white at micropilar end of seed

${ }^{2}$ Lamprecht (1934, 1940a) did not hypothesize a role for Mic and $m i$ in partly colored seeds, whereas Leakey (1988) speculates that these genes may control color formation in the micropile zone and micropile stripe, respectively, in the presence oft $e$. For brevity, only one allele per homozygous locus is shown. 
The $\mathrm{F}_{2}$ from 'Early Wax' x 5-593 gave a good fit to a 63:1 ratio [colored seeds (including partly colored seeds) : white seeds] in both years (Table 1). The combined data also gave a good fit to a 63:1 ratio. We propose to explain the white seed segregants in our data by gene action analagous to that of the $L$ gene of Schreiber (1934, 1940). In his model, seed color produced by $\mathrm{t}$ together with partial coloration genes such. as $\mathrm{Z}$ could be either reduced in area or completely extinguished by the action of $L$, depending on which alleles are present at $L$ and the partial coloration loci. We hypothesize that 'Early Wax' carries $t$ and two recessive genes that completely extinguish all color effects of all partial coloration genes.

Allelism test of 7-480 WFS. A single plant with white flowers and white seeds was selected from the $\mathrm{F}_{2}$ of the cross 'Early Wax' $\times$ 5-593 and was designated 7-480 WFS. The $36 \mathrm{~F}_{1}$ plants from the allelism test cross 'Early Wax' $x$ 7-480 WFS had white flowers and white seeds (data not shown). From these results it is inferred that 7-480 WFS has the same genotype for white flowers and seeds as 'Early Wax'.

$7-480 W F S \times 5-593 F_{2}$. The segregation in $\mathrm{F}_{2}$ confirms the results of the allelism test and supports the hypothesis that three recessive genes control white seed color in 'Early Wax' (Table 3 ). The $\mathrm{F}_{2}$ data from 7-480 WFS $\times 5-593$ can also be arranged into three classes: purple flowers and solid black seed, 372 plants; white flowers and partly colored seed, 111 plants; and white flowers and all white seed, four plants. The good fit for a 15:1 ratio between partly colored and white seeds for plants with white flowers suggests that two genes may be involved in the expression of all white seed coats, i.e., pigmentation only requires one dominant allele at either locus (Table 3 ).

All the colored and partly colored seeds segregated for only one color, black (Table 3). Evidently, 7-480 WFS has the genotype $V V$, which prevents segregation for brown seed. It is apparent that the $V$ locus has no effect on the segregation frequency of white seed coat in this material.

Analysis of backcross data. From $\mathrm{F}_{2}$ data we developed the hypothesis that three genes control the expression of white seed coat in 'Early Wax'. We have shown that one of these genes must be $\mathrm{t}$, and for the two remaining genes we propose the gene symbols ers and ers2, two recessive genes for erasure. Thus, we hypothesize that 'Early Wax' has the genotype $t$ t ersers ers2ers2, and the $\mathrm{F}_{1}$ of 'Early Wax' $\times 5-593$ has the genotype Tt Ersers Ers2ers 2 . The cross 'Early Wax' $\times \mathrm{F}_{1}$ ('Early Wax'

Table 3. Classification of two populations of common bean for flower color, seed color, and partial coloration of the seed: $F_{2}\left(F_{2}\right.$ progeny from the cross 7-480 WFS $x$ 5-593) and $\mathrm{BC}$ (backcross $\mathrm{F}_{1}$ progeny from the cross 'Early Wax' x $F_{1}$ ('Early Wax' x 5-593).

\begin{tabular}{|c|c|c|c|c|c|c|}
\hline \multirow[b]{4}{*}{ Population } & \multicolumn{6}{|c|}{ Flower color } \\
\hline & \multirow{3}{*}{$\frac{\text { Purple }}{\begin{array}{c}\text { Solid } \\
\text { black } \\
\text { seed }\end{array}}$} & \multicolumn{5}{|c|}{ White flower } \\
\hline & & \multicolumn{3}{|c|}{ Solid seed color } & \multicolumn{2}{|c|}{$\begin{array}{c}\text { Partial seed } \\
\text { color }\end{array}$} \\
\hline & & Black & Brown & White $^{z}$ & Black & $\overline{\text { Brown }}$ \\
\hline & \multicolumn{6}{|c|}{ No. of plants } \\
\hline $\mathrm{F}_{2}$ & 372 & 8 & & 4 & 103 & 0 \\
\hline $\mathrm{BC}$ & 41 & & 34 & 14 & 17 & 22 \\
\hline
\end{tabular}

${ }^{7}$ For the $\mathrm{F}_{2}$ population the $\mathrm{x}^{2}(63: 1)$ for colored (including partly colored) seed : white seed was $1.71, P=0.19$, and the $x^{2}(45: 15: 1)$ for purple flowers and solid black seed : white flowers and nonwhite seed : white flowers and all white seed was $1.92, P=0.38$. For the $\mathrm{BC}$ population the $\mathrm{x}^{2}(7: 1)$ for colored (including partly colored) seed : white seed was $0.29, P=0.59$, $x$ 5-593) will generate eight genotypes with respect to our model. Four of these genotypes will have $T t$, expressing completely colored seeds, and the remaining four genotypes will have $t t$, potentially expressing partial seed color. One of these genotypes will be white, tt ersers ers2ers2, giving the expected backcross ratio of 7 colored : 1 white seeds. For the cross 'Early Wax' $\mathrm{x}$ $F_{1}$ ('Early Wax' $x$ 5-593) the $F_{1}$ progeny segregation gave a good fit to a 7:1 ratio for colored (including partly colored) seeds : white seeds, which supports the hypothesis (Table 3).

The remaining three genotypes with $t t$ are $t$ Ersers ers2ers2, $t t$ ersers Ers2ers2, and $t t$ Ersers Ers2ers2, all of which can express partial seed coloration. When these genotypes are progeny-tested, only two segregation ratios for colored : white are expected, viz., 3:1 and 15:1, and the expected frequency of these segregatation ratios in $\mathrm{BC}_{1}-\mathrm{F}_{2}$ will be $2: 1$, respectively. The data from the $\mathrm{BC}_{1}-\mathrm{F}_{2}$ show segregation for only two ratios, 3:1 and 15:1, as our model predicted (Table 4). Plot 9-149 was strongly deviant from a 3:1 $(P=0.04)$, tending more toward a $1: 1$ than a $3: 1$ ratio, but this is possibly a random deviation in a group of 23 progenies. Only plots 9-159 and 9-170 appear to have a much better fit to a $15: 1$ than a $3: 1$ ratio. These results deviate strongly from the prediction based on our three-gene model. There is only one chance in a hundred that these results would occur by chance alone, and additional analysis is necessary (Table 5).

By examining remnant seed from the 23 progenies, it was discovered that there was a perfect correspondence between the extent of seed coloration in the parent and the segregation ratio of the progeny (Table 5). All 21 parents segregating for 3 colored : 1 white had very limited seed coloration, i.e., the seed phenotypes were either bipunctata, arcus, or eye. The only two parents that segregated 15 colored $: 1$ white had extensive seed coloration, i.e., either sellatus-maximus or major-minor phenotypes. We use these hyphenated names because the range of

Table 4. Segregation for partly colored or all white seed coats of common bean in $23 \mathrm{BC}_{1}-\mathrm{F}_{2}$ progenies from partly colored $\mathrm{BC}_{1}-\mathrm{F}_{1}$ parents.

\begin{tabular}{|c|c|c|c|c|}
\hline \multirow[b]{2}{*}{$\begin{array}{l}\text { Plot } \\
\text { no. }\end{array}$} & \multicolumn{2}{|c|}{ Seed type } & \multirow[b]{2}{*}{$\begin{array}{c}\chi^{2} \\
3: 1 \\
\end{array}$} & \multirow[b]{2}{*}{$\begin{array}{c}\chi^{2} \\
15: 1 \\
\end{array}$} \\
\hline & $\begin{array}{c}\text { Partly } \\
\text { colored }\end{array}$ & White & & \\
\hline $9-148$ & 29 & 8 & 0.225 & \\
\hline $9-149$ & 13 & 10 & 4.188 & \\
\hline $9-150$ & 30 & 9 & 0.077 & \\
\hline $9-151$ & 41 & 9 & 1.307 & \\
\hline $9-152$ & 36 & 6 & 2.571 & 4.608 \\
\hline $9-153$ & 26 & 12 & 0.877 & \\
\hline $9-154$ & 16 & 4 & 0.267 & \\
\hline $9-155$ & 22 & 11 & 1.222 & \\
\hline 9.156 & 31 & 13 & 0.485 & \\
\hline $9-157$ & 32 & 15 & 1.199 & \\
\hline 9.158 & 24 & 7 & 0.097 & \\
\hline $9-159$ & 44 & 2 & 9.883 & 0.86 \\
\hline $9-160$ & 34 & 16 & 1.307 & \\
\hline $9-161$ & 23 & 9 & 0.167 & \\
\hline $9-162$ & 20 & 11 & 1.817 & \\
\hline $9-163$ & 13 & 3 & 0.333 & \\
\hline $9-164$ & 26 & 7 & 0.253 & \\
\hline $9-165$ & 37 & 16 & 0.761 & \\
\hline $9-166$ & 26 & 14 & 2.133 & \\
\hline $9-167$ & 27 & 9 & 0.00 & \\
\hline $9-168$ & 14 & 6 & 0.267 & \\
\hline $9-169$ & 14 & 6 & 0.267 & \\
\hline $9-170$ & 28 & 3 & 3.882 & 0.618 \\
\hline
\end{tabular}


Table 5. Frequency of the two segregation ratios (partly colored : white seed coats) observed in progeny tests $\left(\mathrm{BC}_{1}-\mathrm{F}_{2}\right)$ of partly colored segregants of common bean from 'Early Wax' $\times \mathrm{F}_{1}$ ('Early Wax' $\times 5-593)$.

\begin{tabular}{|c|c|c|c|}
\hline$\frac{\text { Ratios }}{\text { Colored : white }}$ & $\begin{array}{l}\text { Progenies } \\
\text { (no.) }\end{array}$ & $\begin{array}{c}x^{2} \\
2: 1^{2}\end{array}$ & $P$ \\
\hline $\begin{array}{r}3: 1 \\
15: 1\end{array}$ & $\begin{array}{r}21^{y} \\
2^{x}\end{array}$ & 6.289 & 0.01 \\
\hline
\end{tabular}

${ }^{2}$ Expected frequency of 2:1 for the ratios 3:1 and 15:1, respectively. 'Parents were bipunctata, arcus, or eye (Lamprecht, 1934).

${ }^{x}$ Parents were either sellatus-maximus or major-minor (the large variation within each plant straddled two phenotypic classes).

seed types within each parent appeared to straddle two of Lamprecht's (1934) seed classes. It is highly unlikely that this perfect correspondence between parental seed phenotypes and progeny segregation ratios is a coincidence. We believe that these results reveal another refinement that can be added to our genetic model. It appears that ers and ers2 are not interchangeable "duplicate" genes that block expression of genes for partial seed coloration. Instead, each affects a separate group of tests color zones (Prakken, 1972). One of the genes, ers2, prevents pigment formation only in color zones near the hilum, but it expresses only in the presence of the other erasure gene, ers/ ers. The latter gene prevents pigment formation only in color zones beyond those close to the hihrm. Thus, ers and ers 2 block pigment formation in a two-stage process beginning in the more distal color zones (ers) and ending in the proximal zones (ers2) near the hilum.

It is probable that ers is a synonym for the restricts locus of Prakken (1972), which was detected by him (1972) in the analysis of the $F_{2}$ from the cross 'Wagenaar' $\times$ 'Soldaat $K$ '. The symbol restr was used for this locus. He showed that exactly one-fourth of the partly colored $\mathrm{F}_{2}$ segregants had virgarcus pattern with color restricted to color zones 1 through 6 (never extending into zones 7 and 8), whereas the remaining threefourths of the partly colored $\mathrm{F}_{2}$ segregants had color patterns ranging from sellatus to minimus (Table 2). The similarity of action observed for ers and restr can be illustrated with data in Table 6. For progenies 9-159 and 9-170, if one totals all the classes from bipunctata through eye (referred to as soldier) and then totals all the classes from sellatus through colored (referred to as trout), one gets 42 trout : 30 soldier : 5 white. The $x^{2}$ (9:6: 1 ) for the above classes is $0.09, P=0.96$. We hypothesize that two heterozygous genes are segregating such that the double recessive at each locus determines expression of soldier series phenotypes. If ers/ers (restr-type action) is one of these genes, then there must be another locus segregating that determines soldier series phenotypes in the presence of Ers/-. The genetic model of Table 2 is not adequate for our data because it provides no way for trout series phenotypes to segregate for such a large proportion of soldier series phenotypes. Leakey (1988) uses Prakken's (1972) data for restr to give specificity to the vague e gene, but we prefer to discard the e symbol and use ers rather than restr because the restr symbol does not conform to current rules for gene nomenclature (Myers and Weeden, 1988).

The $\mathrm{BC}_{2}-\mathrm{F}_{2}$ of $t$ ers ers 2 into 5-593 was achieved with the cross 8-525 WFS $\times 5-593$. The $\mathrm{F}_{2}$ segregated into three classes: purple flowers and solid black seed, 236 plants; white flowers and partly colored seed, 66 plants; and white flowers and all white seed, three plants. A $x^{2}$ test of a 48:15:1 ratio for the three above classes gave $x^{2}=1.307, P=0.52$. This gives further confirmation to the three-gene model, including the twofactor interaction between the ers genes. Additional backcrosses are needed to determine whether 5-593 carries partial coloration genes in both groups of color zones, i.e., those close to the hilum and those more remote. The partly colored segregants included bipunctata, eye, and a preponderance of extensively colored phenotypes. The preliminary evidence suggests that 5593 has the genotype T Ers Ers2 Z Bip Arc diff exp, whereas 'Early Wax' has the genotype t ers ers 2 z bip arc Diff Exp.

It may be asked how one can be sure that $t$ ers ers 2 is not being mistaken for the other triple recessive genotype for white seed coat, $c d j$. The former genotype has white flowers due to $\mathrm{t}$, whereas the latter genotype has colored" flowers, i.e., the genes $\mathrm{c}, d$, and $\mathrm{j}$, either individually or in any combination, do not produce white flowers. The recessive allele $\mathrm{c}$ produces offwhite color(s) that are easily distinguished from either pure white or the many colors in the yellow-black series (Prakken, 1970). None of these off-white colors (buff) were ever seen in the segregating progeny involving crosses oft ers ers2 with 5-593. Similarly, $\mathrm{j}$ produces a dull seed coat, whereas no dull seed coats were ever observed in our experimental materials, i.e., both 5-593 and 'Early Wax' carry $J$ and have shiny seed coats. There can be no doubt that the triple recessive genotype of 'Early Wax' is different from $\mathrm{c} d j$.

Partial coloration phenotypes. For the $\mathrm{F}_{2}$ progeny of the cross 'Early Wax' $\times 5-593$, a single seed from each plant with partial coloration was selected as representative of that plant. These seeds were arranged in a linear sequence from least colored to most colored. The distribution appeared continuous in most of its regions, and we were not able to make unambiguous classification into the numerous phenotypes reported in the literature (Emerson, 1909; Lamprecht, 1934, 1940a; Miyake et al., 1930; Schreiber, 1934, 1940; Tschermak, 1912). The phenotypes included unipunctata, bipunctata, arcus, Iaciniata, virgarcus, eye, sellatus, maximus, major, minor, and minimus. For the $F_{1}$ progeny of the cross 'Early Wax' $\mathrm{F}_{1}$ ('Early Wax' x 5-593) the same linear arrangement of seeds was used. This distribution of seed types was classifiable with less ambiguity than the $\mathrm{F}_{2}(\mathrm{Ta}-$ ble 6). The "virgarcus plus" phenotype is a new name that was required to describe a class that is like virgarcus except that the arcs form a complete ring around the hilum.

The genotypes proposed by Lamprecht (1940a) and Leakey (1988) and their corresponding phenotypes are listed in Table 2. The genes Bip and Arc in their dominant state cause extension of color on partly colored seeds, whereas the genes cliff and exp do so in their recessive state. Bip permits expression of color beyond the two dots of color on opposite sides of the hilum, and $\operatorname{Arc}$ produces arcs of color in a "horseshoe" around the hilum that nearly connects the bipunctata dots. Leakey (1988) speculates that the dot of color at the micropile end of the hilum in bipunctata phenotypes is due to the gene, Mic, whereas Lamprecht (1940b) described a pattern of small dots originating at the micropile and flowing down both sides of the seed that are controlled by this dominant gene (Table 2). According to Lamprecht (1934, 1940a) Bip and Arc produce the virgarcus type, a "ring and tail" pattern. Leakey (1988) speculates that the gene, $m i$, for micropile stripe, must be present to obtain the virgarcus pattern (Table 2), whereas Lamprecht (1934, 1940a) attributes the micropile stripe to the effects of $\operatorname{Arc}$ alone. In the presence of Bip and/or Arc, the genes cliff and exp produce the extensively colored types called maximus, major, minor, and minimus (Table 2). The interactions of the latter two genes with the former two were never fully elucidated by Lamprecht. There 
Table 6. Segregation of $\mathrm{BC}_{1}-\mathrm{F}_{1}$ parents and their $\mathrm{BC}_{1}-\mathrm{F}_{2}$ progenies for partly colored seed phenotypic classes from the cross 'Early Wax' $\mathrm{x}$ F, ('Early Wax' $\times 5-593)$ in common bean.

\begin{tabular}{|c|c|c|c|c|c|c|c|c|c|c|c|c|c|c|c|c|}
\hline \multirow{2}{*}{$\begin{array}{l}\text { Progeny } \\
\text { no. }\end{array}$} & \multirow{2}{*}{$\begin{array}{l}\text { Parental } \\
\text { phenotype }\end{array}$} & \multicolumn{14}{|c|}{ Classes of partly colored seeds in $\mathrm{BC}_{1}-\mathrm{F}_{2}{ }^{2}$} & \multirow[b]{2}{*}{ Total } \\
\hline & & Wh & $\mathrm{Bi}$ & $\mathrm{La}$ & $\mathrm{Ar}$ & $\mathrm{Vi}$ & $\mathrm{Vi}+$ & Lo & Ey & $\mathrm{Se}$ & $\mathrm{Mx}$ & $\mathrm{Mj}$ & $\mathrm{Mn}$ & Ms & $\mathrm{Co}$ & \\
\hline $9-148$ & Bipunctata & 8 & 10 & & . & 3 & 5 & & 6 & & 5 & & & & & 37 \\
\hline $9-160$ & Bipunctata & 16 & 19 & & & & & & 12 & 2 & & & 1 & & & 50 \\
\hline $9-161$ & Bipunctata & 9 & 6 & & & & & & 8 & 3 & & & 6 & & & 32 \\
\hline $9-162$ & Bipunctata & 11 & 9 & 5 & & & & & & 6 & & & & & & 31 \\
\hline $9-150$ & Eye & 9 & 3 & & & & & & 17 & 3 & 4 & 2 & 1 & & & 39 \\
\hline $9-153$ & Eye & $\therefore$ & & & & & 9 & & 11 & & 1 & & 3 & & 2 & 38 \\
\hline $9-163$ & Eye & 3 & 3 & & & 1 & & & 6 & & & 3 & & & & 16 \\
\hline $9-154$ & Arcus & 4 & & 6 & 4 & & & & & & 4 & 2 & & & & 20 \\
\hline $9-155$ & Arcus & 11 & & 7 & 13 & & & & & & 1 & 1 & & & & 33 \\
\hline $9-156$ & Arcus & 13 & & 3 & 20 & & & & & & 5 & 3 & & & & 44 \\
\hline $9-157$ & Arcus & 15 & & 2 & 19 & & & & & & 2 & 9 & & -. & & 47 \\
\hline $9-167$ & Arcus & 9 & & 7 & 8 & & & & & & 3 & 8 & 1 & & & 36 \\
\hline $9-168$ & Arcus & 5 & & & 13 & & & & & & & 1 & 1 & & & 20 \\
\hline $9-169$ & Arcus & 6 & & & 8 & & & & & & 1 & 3 & 2 & & & 20 \\
\hline $9-159$ & Sellatus-maximus & 2 & 7 & 1 & 3 & & 2 & & 5 & 4 & 7 & 8 & 6 & 1 & & 46 \\
\hline $9-170$ & Major-minor & 3 & & & 6 & & & & 6 & & 1 & 8 & & 1 & 6 & 31 \\
\hline
\end{tabular}

${ }^{2} \mathrm{Wh}=$ white, $\mathrm{Bi}=$ bipunctata, $\mathrm{La}=$ laciniata, $\mathrm{Ar}=$ arcus, $\mathrm{Vi}=$ virgarcus, $\mathrm{Vi}+=$ virgarcus plus, Lo $=$ lobata, $\mathrm{Ey}=$ eye, $\mathrm{Se}=$ sellatus, $\mathrm{Mx}=$ maximus, $\mathrm{Mj}=$ major, $\mathrm{Mn}=$ minor, $\mathrm{Ms}=$ minimus, $\mathrm{Co}=$ colored.

is a fifth gene, $\mathrm{Z}$, in the Lamprecht hypothesis that controls patterns in partly colored seeds. Tschermak (1912) was the first to report a $1: 2: 1$ ratio for $z_{2} / z_{2}$ giving the small eye pattern (Lamprecht's virgarcus) : the heterozygote $\mathrm{Z}_{2} / \mathrm{z}_{2}$ giving the piebald pattern covering over half of the seed coat $: Z_{2} / Z_{2}$ giving a larger eye covering $=25 \%$ of the seed coat (Lamprecht's sellatus). The $\mathrm{Z}_{2}$ of Tschermak (1912) is now designated $\mathrm{Z}$ (Bassett, 1989; Lamprecht, 1934). The interactions of $\mathrm{Z}$ with Bip, Arc, diff, and exp have never been investigated. It is obvious that there are numerous voids and a few contradictions in the genetic model (Table 2), but these will not be discussed here.

Inspection of the data in Table 6 reveals that none of the 23 parents were true-breeding. It is also apparent that all of the bipunctata, eye, and arcus parents segregated for extensively colored progeny. For the five bipunctata parents, if one totals all the classes from bipunctata through eye (soldier) and then totals all -the classes from sellatus through colored (trout), one can calculate the proportion of extensively colored progeny as trout/(soldier + trout). For the five bipunctata parents this proportion is exactly 0.25 , indicating that a single recessive gene is needed for expression of the trout series. The same procedure can be done for the five eye parents, and the resulting proportion is 0.26. Again, a single recessive gene is indicated. For the 11 arcus parents the analysis reveals two groups. Parental plots 9$155,9-156,9-158,9-164$, and 9-168 give a good fit to a $3: 1$ ratio for soldier : trout $\left(x^{2}=0.915, P=0.34\right)$. The remaining six arcus plots, 9-154, 9-157, 9-165, 9-166, 9-167, and 9-169, give a good fit to a 9:7 ratio for soldier : trout $\left(X^{2}=0.148, P\right.$ $=0.70$ ). If the extensively colored phenotypes really require that diff be homozygous for expression, then all of the above parents with progeny fitting a 3:1 ratio must have been heterozygous at diff to allow the segregation. This is highly improbable $\left[(1 / 2)^{15}\right]$ because in a backcross equal probability of segregation for the heterozygote and homozygote is expected. Clearly, previous literature provides no explanation for these data, and we can offer no genetic model for these partial coloration data. It should also be noted that all 11 arcus parents fail to segregate for bipunctata and virgarcus. Lamprecht (1940a) provides two genotypes for arcus, BipBip arcarc and Bipbip arcarc, and the latter genotype, when selfed, will segregate for the bipunctata genotype, bipbip arcarc (Table 2). It is highly improbable that the 11 arcus parents had the homozygous genotype for arcus by chance when, on average, half of the 11 should have had the heterozygous genotype for arcus. We hypothesize that the cross 'Early Wax' x 5-593 segregates in $\mathrm{F}_{2}$ for $t$, ers, ers2, Z, Bip, Arc, cliff, exp, and perhaps for Mic, mi, and other genes not yet discovered. Also, we suspect that the interactions of $\mathrm{Z}$ with Bip, Arc, cliff, and exp make the partly colored phenotypes particularly difficult to classify.

These observations and critical analysis are not made to disparage the extensive previous literature on partly colored seeds. On the contrary, we regard these findings as valid and highly valuable, but we also regard the genetics of partly colored seeds as incomplete. Several characteristics of genes for partly colored seeds have prevented any further progress: great variability of the phenotype of seeds on a single plant that is homozygous at all partial coloration loci, intermediate and highly variable phenotypes of seeds with heterozygosity for these loci, and a very complex system of interaction among genes for partly colored seeds. The wide variability of expression of partly colored genotypes, especially in heterozygotes and the more extensively colored patterns, makes it necessary to progeny-test these segregants to establish genotypic classes with precision, but this requirement creates an excessive experimental burden. Use of molecular markers may facilitate genetic classification of phenotypes and improve knowledge of seed coat pattern genetics. Specifi- 
cally, one might develop a recombinant inbred series that was segregating for 50 to 100 well-distributed RFLP and isozyme markers and segregating for most of the partial coloration loci. By searching for linkages between molecular markers and partial coloration loci, it would be possible to associate particular chromosome regions with coloration in particular zones of the seed coat and associate these regions with known (and perhaps as yet undiscovered) partial coloration loci. In this way the nonallelic interactions among the partial coloration loci might be uncovered.

\section{Literature Cited}

Bassett, M.J. 1989. List of genes-Phaseolus vulgaris L. Annu. Rpt, Bean Improv. Coop. 32:1-15.

Dickson, M.H. and R. Petzoldt. 1988. Deleterious effects of white seed coat due top gene in beans. J. Amer. Soc. Hort. Sci. 113:111114.

Emerson, R.A. 1909. Inheritance of color in seeds of the common bean, Phaseolus vulgaris. Neb. Agr. Expt. Sta. Rpt. 22:65-101.

Lamprecht, H. 1934. Zur Genetik von Phaseolus vulgaris.VIII.Über Farbenverteilung und Vererbung der Teilfarbigkeit der Testa. Hereditas 19:177-222.

Lamprecht, H. 1935. Zur Genetik von Phaseolus vulgaris. XII. Über die Vererbung der Bluten- und Stammfarbe. Hereditas 21:129-166.

Lamprecht, H. 1940a. Zur Genetik von Phaseolus vulgaris. XVI. Weitere Beiträge zur Vererbung der Teilfarbigkeit. Hereditas 26:277291.

Lamprecht, H. 1940b. Zur Genetik von Phaseolus vulgar-is. XVIIXVIII. Zwei neue Gene fur Abzweichen auf der Testa, Punc und Mip, sowie über die Wirkung von V und Inh. Hereditas 26:292304.
Lamprecht, H. 1948. On the effect and linkage of genes transmitted from Phaseolus coccineusto Ph. vulgaris. Agr. Hort. Genet. 6:6481.

Lamprecht, H. 1961. Die Vererbung der rezessiv roten Testafarbe von Phaseolus. Sowie Bemerkungen zur Manifestation und Symbolik von Testafarbgenen. Agr. Hort. Genet. 19:344-359.

Leakey, C.L.A. 1988. Genotypic and phenotypic markers in common bean, p. 245-327. In: P. Gepts (cd.). Genetic resources of Phaseolus beans. Kluwer Academic, Boston, Mass.

Miyake, K., Y. Imai, and K. Tabuchi. 1930. Contributions to the genetics of Phaseolus vulgaris. J. College Agr. Tokyo 11:1-20.

Myers, J.R. and N.F. Weeden. 1988. Aproposed revision of guidelines for genetic analysis in Phaseolus vulgaris L. Annu. Rpt. Bean Improv. Coop. 31:16-19.

Prakken, R. 1934. Inheritance of colors and pod characters in Phaseolus vulgaris L. Genetics 16:177-294.

Prakken, R. 1970. Inheritance of colour in Phaseolus vulgaris L .II. A critical review. Med. Landb. Wageningen, 70-23.

Prakken, R. 1972. Inheritance of colours in Phaseolus vulgaris L. III. On genes for red seedcoat colour and a general synthesis. Med. Landb. Wageningen, 72-29.

Sax, K. 1923. The association of size differences with seed-coat pattern and pigmentation in Phaseolus vulgaris. Genetics 8:552-560.

Schreiber, F. 1934. Zur Genetik der weissen Samenfarbe bei Phaseolus vulgaris. Züchter 6:53-61.

Schreiber, F. 1940. Die Genetik der Teilfarbung der Bohnensamen (Phaseolus vulgaris). Zeitschr. Ind. Abst. Vererbungsl. 78:59-114.

Tschermak, E.v. 1912. Bastardierungsversuche an Levkojen, Erbsen und Bohnen mit Rucksicht auf die Faktorenlehre. Zeitschr. Ind. Abst. Verebungsl. 7:81-234.

Yarnell, S.H. 1965. Cytogenetics of the vegetable crops. IV. Legumes (continued). Bet. Rev. 31:247-330. 